\title{
First Confirmed Record of Striped Hyaena (Hyaena hyaena) Den in Nepal
}

\section{Khanal $C^{1,2,3^{*}}$, Baniya $S^{2}$ and Acharye $\mathbf{M}^{2}$}

${ }^{1}$ Friends of Nature (FON) Nepal, Organization of Environment and Biodiversity Conservation, Kathmandu 44600, Nepal ${ }^{2}$ Institute of Forestry, Tribhuvan University, Pokhara, Nepal

\begin{abstract}
Hyaena is one of the twenty seven mammals species protected by National Park and Wildlife conservation ACT1973 of Nepal. Study of hyaena is lacking in Nepal so less information is available about this species in country. A single den was recorded in Kalapani community forest of Deukhuri Valley in Dang District located at the elevation of $282 \mathrm{~m}$ above sea level. Signs, camera trap images and video confirm the den of striped hyaena which is first confirmed record of Hyaena den in Nepal.
\end{abstract}

Keywords: Camera trap; Mammals; Community forest; Striped hyaena

Striped Hyaena (Hyaena hyaena) is classified as "Near threatened" on IUCN RedList of threatened species [1]. Nationally, it has been assessed as Endangered with estimated populations fewer than 100 individuals in Nepal [2]. However, very little information is available in Nepal about its distribution and ecology. Striped hyaena generally favors arid to semi-arid environments [3-5] where water is available within $10 \mathrm{~km} \mathrm{[6,7].} \mathrm{They} \mathrm{appear} \mathrm{to} \mathrm{avoid} \mathrm{open} \mathrm{desert} \mathrm{and} \mathrm{dense} \mathrm{thickets} \mathrm{and}$ forests [6-8] and have only been found below 3,300 $\mathrm{m}[6,7,9]$. Striped hyaena generally favors and consistently revisits larger caves for resting $[6,7,10,11]$. The striped hyaena is monogamous, with the male helping the female to establish a den, raise young and feed her when cubs are born. Striped hyena cubs are reared in dens and intense digging behaviour in the females announces parturition [6]. Dens may be holes dug by the mother, holes formed and abandoned by other species $[9,12]$ or deep, natural, and sometimes complex, caves $[8,11,13]$. Striped hyaena is one of the protected mammals by National Park and Wildlife conservation ACT, 1973AD. Feeling the important of this species and relatively less information available striped hyaena was kept as a protected mammal of Nepal. Wildlife act-1973 [2,14-18] are past evidence which shows the presence records of hyaena in different period in Nepal. This all provides only the presence evidence of Hyaena in Nepal. Research on this species is limited so there is little information about this species and no any records of den are available in country before. This is the first confirmed documentation of Hyaena den in Nepal (Figure 1).

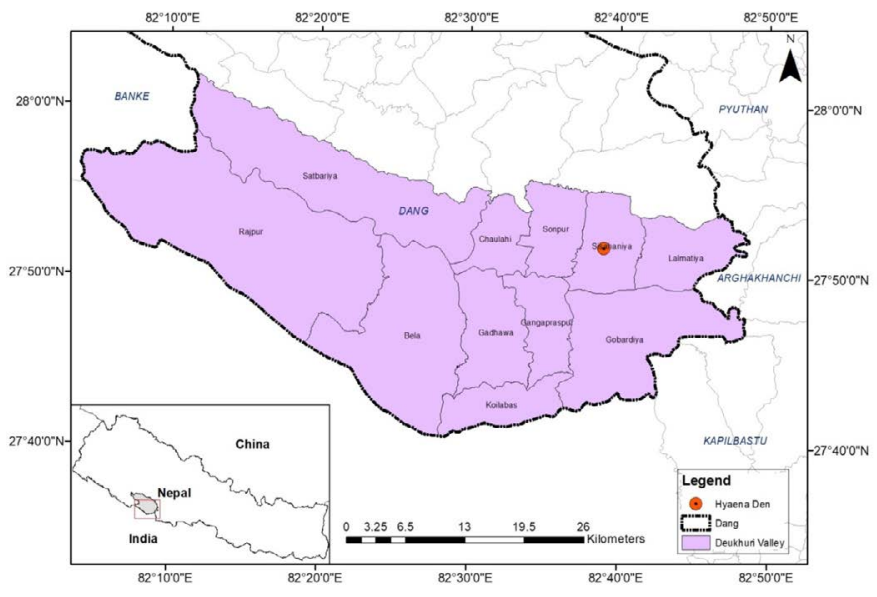

Figure 1: Map showing Hyaena den.
Information about the den and its location was firstly known through the local forest users and forest guard of the Kalapani community forest of Deukhuri Valley in late 2012. Signs around the den were recorded and the confirmation of signs was done in 2013. When the signs were confirmed to be of striped hyaena further confirmation was done through photos and videos obtained from camera trapping. Hyaena is also using this den for breeding. Camera trapping done in the den site for four years (2014 to2017) shows that hyaena are breeding in this den. Two cubs along with adult male and female were recorded in 2015 and recently in July and august 2017 two cubs are seen in den.

Camera trap programmed in day and night activation mode was placed at the base of a Dalbergia sissoo and Acacia catechu focusing on the cave entrance (Figure 2). After the assurance through camera trap images and videos, morphometric measurements of the dimensions of the den followed by ocular survey of the surrounding habitat was carried out. The periphery of the den was examined to look for the presence of further entrances and also for the possible carcasses of hyaena prey. We recorded bones and skull of dog, goat, and cow, skin and wool of sheep also chicken feathers near the den site. This evidence shows that hyaena are scavenging or preying domestic animals and birds.

The surrounding area of the den was densely populated with the riverine crops i.e. Acacia catechu and Dalbergia sissoo and bushes all along. The width and average breadth of the den entrance were measured 0.91 meter and 0.45 meter respectively (Figure 3 ). Depth of the den, however, could not be measured due to lack of proper measuring instrument inside the den. The den is around 800 meter far from the village nearby the forest. An artificial conservation pond is constructed in the forest which lies around 300 meter south of the den. This water is sustained in the pond for the whole year. Den is also located very close to a dry stream, $5 \mathrm{~m}$ north of den. This stream remains dry whole of the year except in monsoon. Kalapani community forest is declared as grazing free community forest so there is no grazing pressure in forest.

*Corresponding author: Khanal C, Institute of Forestry, Tribhuvan University, Pokhara, Nepal, Tel: 9779841820954; E-mail: chiran_khanal2011@hotmail.com

Received August 17, 2017; Accepted August 25, 2017; Published August 31, 2017

Citation: Khanal C, Baniya S, Acharye M (2017) First Confirmed Record of Striped Hyaena (Hyaena hyaena) Den in Nepal. J Biodivers Endanger Species 5: 195. doi: 10.4172/2332-2543.1000195

Copyright: @ 2017 Khanal C, et al. This is an open-access article distributed under the terms of the Creative Commons Attribution License, which permits unrestricted use, distribution, and reproduction in any medium, provided the original author and source are credited. 
Citation: Khanal C, Baniya S, Acharye M (2017) First Confirmed Record of Striped Hyaena (Hyaena hyaena) Den in Nepal. J Biodivers Endanger Species 5: 195. doi: 10.4172/2332-2543.1000195

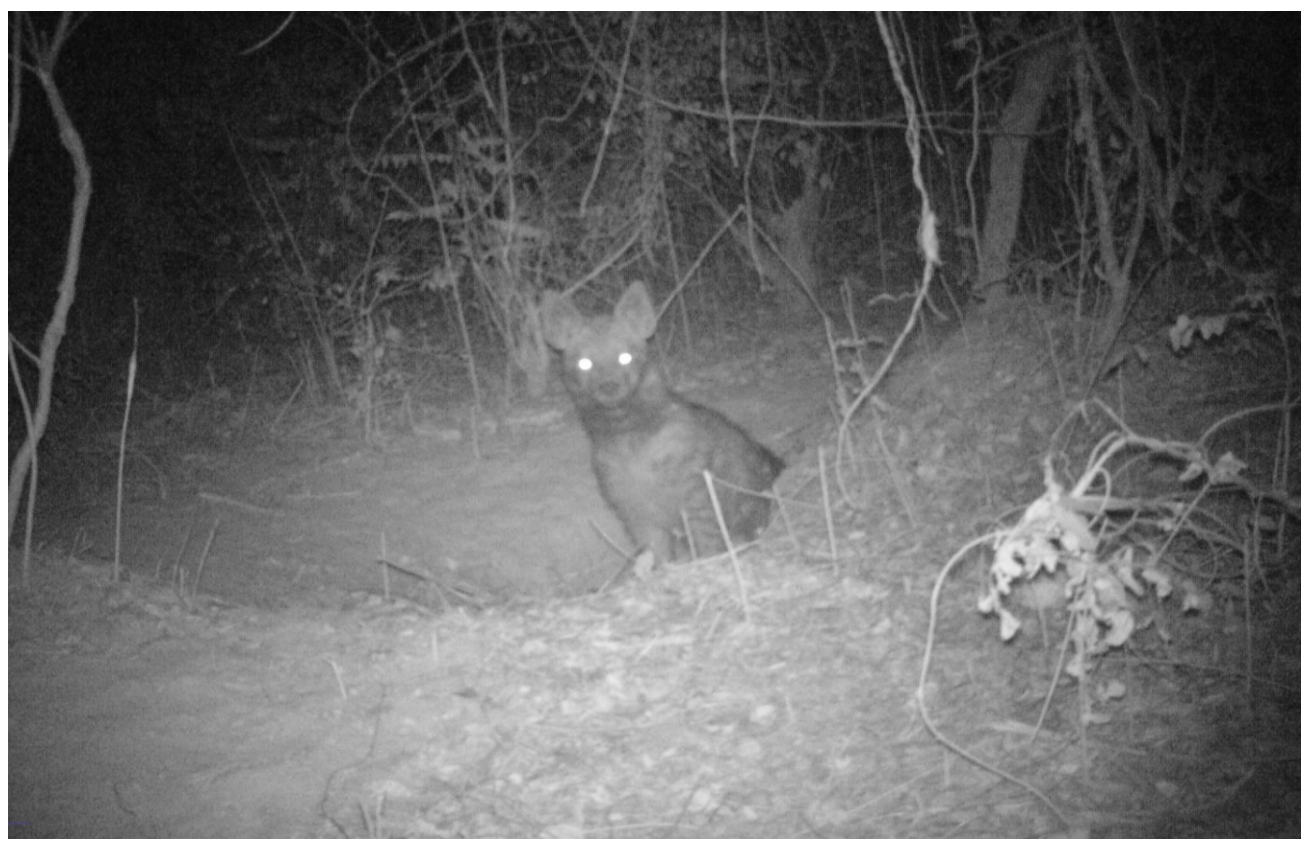

Figure 2: Hyaena coming out of the den.

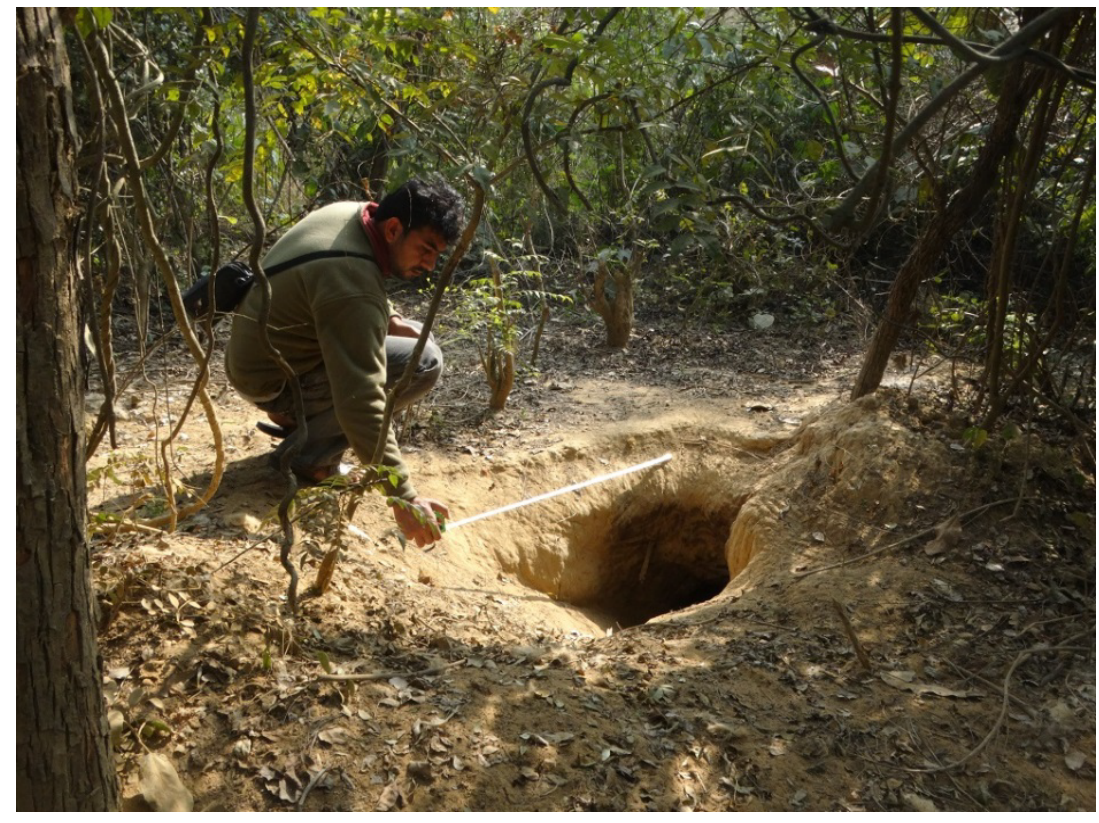

Figure 3: Author taking measurement of den.

Nevertheless, local people frequently visit the forest for their needs of fuel wood, fodder and grass for cattle. The average minimum and maximum temperatures recorded in this area are about $13^{\circ} \mathrm{C}$ and $40^{\circ} \mathrm{C}$ respectively.

Striped hyaena, although nationally endangered species has not yet received a significant attention for conservation and research from the Government. Having been named the protected mammal of Nepal, but there are too little information about the ecology, denning activities and threats to the species in the country. Thus, further research on the ecology, behavior and conservation awareness from the grass root level is necessary.

\section{Acknowledgement}

We would like to acknowledge Hariyo Ban Program/ Terai Arc Landscape Program, WWF Nepal for funding "Camera trap survey in 2013/2014" and The Rufford Foundation for their financial support for Hyaena research in Dang in 2015, 
Citation: Khanal C, Baniya S, Acharye M (2017) First Confirmed Record of Striped Hyaena (Hyaena hyaena) Den in Nepal. J Biodivers Endanger Species 5: 195. doi: 10.4172/2332-2543.1000195

Page 3 of 3

2016 and 2017, Department of Forest, Nepal for providing the camera trapping permission. We are thankful to District Forest Office, Dang, Narti and Gadawa Community Forest Coordination Committee for their support and coordination during research.

Last but not the least we would like to acknowledge Jeevan Rai for his help in GIS maps, Raju Acharya and Yadav Ghimirey from Friends of Nature (FON Nepal) for their encouragement in research, Tilak Dhakal, Kanchan Thapa, Bhaskar Chaudhary, Manoj Chaudhary, Laxmi Chaudhary from WWF Nepal for their support during first research on hyaena likewise Prateek Pandey, Suman Ghimirey, Bipana Basnet, citizen scientist Sreejana Chaudhary and Nirmala Dandel for their help during the field work.

\section{References}

1. AbiSaid M, Dloniak SMD (2015) Hyaena hyaena. The IUCN Red List of Threatened Species.

2. Jnawali SR, Baral HS, Lee S, Acharya KP, Upadhyay GP, et al. (2011)The Status of Nepal Mammals: The National Red List Series, Department of National Parks and Wildlife Conservation, Kathmandu, Nepal.

3. Hofer H (1998) Striped Hyaena Hyaena (Hyaena) hyaena (Linnaeus, 1758) In: Mills $\mathrm{G}$ and Hofer $\mathrm{H}$ (editors), Hyaenas. Status Survey and Conservation Action Plan, IUCN/SSC Hyaena Specialist Group. IUCN, Gland, Switzerland and Cambridge,UK pp: 21-26.

4. Wagner AP (2013) Hyaena hyaena. In: J.S. Kingdon and M. Hoffmann (eds), Mammals of Africa. In: Carnivores, Pangolins, Equids, Rhinoceroses, Bloomsbury Publishing, London 5: 560.

5. Alam MdS, Khan JA, Kushwaha SPS, Agrawal R, Pathak BJ, et al. (2014) Assessment of suitable habitat of near threatened striped hyaena (Hyaena hyaenaLinnaeus, 1758) using remote sensing and geographic information system. Asian J Geoinform 14: 1-10.

6. Rieger I (1979) A review of the biology of the striped hyaenas, Hyaena hyaena
(Linne, 1758). Saugetierkundliche Mitteilungen 27: 81-95

7. Wagner AP (2006) Behavioral ecology of the striped hyaena (Hyaena hyaena) $\mathrm{PhD}$ Thesis, Montana State University.

8. Heptner VG, Sludskii AA (1988) Mammals of the Soviet Union: Carnivora (hyaenas and cats), Smithsonian Institution Libraries and National Science Foundation, Washington DC 2: 2-3.

9. Roberts TJ (1977) The Mammals of Pakistan. Ernest Benn Limited, London p: 361

10. Kruuk H (1976) Feeding and social behaviour of the striped hyaena (Hyaena vulgaris Desmarest). East African Wildlife J 14: 91-111.

11. Leakey LN, Milledge SAH, Leakey SM, Edung J, Haynes P, et al. (1999) Diet of striped hyaena in northern Kenya. African J Ecol 37: 314-326.

12. Prater SH (1971) The Book of Indian Animals. Bombay Natural History Society Oxford University Press, Bombay.

13. Kerbis-Peterhans JC and Horwitz LK (1992)A bone assemblage from striped hyena (Hyaena hyaena) den in the Negev Desert, Israel. Israel J Zool 37: 225-245.

14. Suwal R, Verheugt YJM (1995) Enumeration of Mammals of Nepal. Biodiversity Profiles Project Publication No. 6. Department of National Parks and Wildlife Conservation. Ministry of Forest and Soil Conservation. His Majesty's Government, Kathmandu.

15. Majupuria TC, Kumar R [Majupuria] (2006) Wildlife and Protected Areas of Nepal [Resources and Management] $S$ Devi Sharanpur, India

16. Baral HS, Shah KB (2008) Wild Mammals of Nepal. Himalayan Nature, Kathmandu.

17. Thapa S (2014) A checklist of mammals of Nepal. Journal of Threatened Taxa 6: 6061-6072.

18. Khanal C (2015) First record of Striped Hyena in Deukhuri Valley, Dang Nepal TigerPaper 42 22-24. 